\title{
The social-cultural aspect of life of Polish population in the Olonets province in the mid-to-late XIX century
}

\author{
Regina Elizaveta Kudriavtceva, ${ }^{1, *}$ and Ekaterina Samylovskaya ${ }^{2}$ \\ ${ }^{1}$ Junior researcher, Saint Petersburg State University, 199034, Saint Petersburg, Universitetskaya emb., 7-9, Russia \\ ${ }^{2}$ Candidate of History, assistant, Department of History, Saint Petersburg Mining University, 199106, 2, 21st Line, St Petersburg, Russia
}

\begin{abstract}
The article is devoted to the problem of analysis of saving the national identity of the ethnic Polish group on the territory of the Olonets province (modern Republic of Karelia, Arkhangelsk and Leningrad Oblast) in the historical perspective. Basing on the analysis of the resources of personal nature (memoirs), as well as the Russian and Polish historiography the main distinguishing characteristics of the national Polish identity on the hostile social-cultural environment were studied. Due to the research the authors concluded that the driving force of preserving the national identity was the religious factor, opening itself in the activity of the exiled priests and such traditional Polish leisure activities such as: choral singing, reading of religious and secular national literature, organization is the educational process.
\end{abstract}

\section{Introduction}

The specific feature of North-West Russian ethnic composition is a longtime historical presence of the Polish population. The first Polish settlers appeared on the territory of the region in the 17 th century, where they were sent after the captivity in the battles during the Time of Troubles. The Polish enclave in the Russian North was preserved till the mid-to-late 19th century in attempts to save its own traditions of the heirs of Grand Duchy of Lithuania and the Polish Crown [1]. The Polish colonies of North-West Russian region grew by means of natural population increase, also they have been replenished with the political prisoners and exiles since the end of the 18th century [2]. The significant population flow of Polish people occurred in the period after the Uprising of 1863-1864 years [3].

In the focus of the research attention there was a territory of the Olonets province in which the territories of modern Karelia, Arkhangelsk and Leningrad Oblast were included. The big Polish community [4], that has saved in spite of the twists and turns of the 20th century, has been existing in Karelia so far. How could such a small colony save its identity in conditions of suppressive environment of Russian language, culture and religion? What was the factor of the social-cultural life of the colony, detached from its homeland, that helped them save their historical memory and nationality?

\section{Main part}

Despite the fact that the main provincial town was Petrozavodsk Polish exiles after the Uprising of 63-64s got into such county towns as Cargopole, Pudozh,
Povenets and Olonets. The total population of these towns was nearly $800-2000$ people [5].

For the period of $1830-1881149$ Polish people were sent to the Olonets province, $88 \%$ of them were sent on the period of 1865-1881 [6, s. 242].

According to the memoirs of the Polish exiles Yulii Konstantinovich Arseniev, who was the governor of the Olonets province in that time, tried to ease the situation for the ones who were coming. Arseniev gave the exiles the right to decide what town to choose advising them to move to Olonets, that had the Polish community by that time [7, s. 33].

The governor's concern and humanity were expressed not only in the invitation to move to the town, but also in creating the special social-cultural microclimate for the exiles. For example, the two officials that were complained on by the exiles were expelled by the governor [7, s. 34]. The living conditions in Olonets differed advantageously from the conditions in neighboring Arkhangelsk province in 1860s [7, s. 34], [8]. However, such favourable conditions were only during the Arseniev's service.

According to the memoirs of the Polish exiles they lived in the rental apartment. For example, according to Edward Pavlovich [7, s. 35], all the apartments were inexpensive and nice, often had 6 rooms; it was also comfortable to live in Olonets: "Soon we have found this such a comfortable housing" with a personal cook - "4 rooms on the ground floor" [7, s. 36]. The Polish didn't have difficulties even in getting the information about the life in Poland, because such newspapers as Independance Beige, Gazeta Polska, Kurier Wileński, Voice, Catholic Review and Europe Review were available to them [7, s. 35].

\footnotetext{
$\overline{\text { * Corresponding author: aethel@yandex.ru }}$
} 
Not only newspapers provided the close link between the exiles and their Homeland, the improvised school for the Polish children, established by the exiles themselves, played the important part. The school, besides the educational purpose, gradually started acting as the cultural centre, providing the exiles with the opportunity of common cultural leisure activities: the Polish gathered to read the national literature, talk and to organize music nights [7, s. 38]. Apart from the school the one more cultural centre was the house of the Doctor Broneslav Napoleon Lobichankovsky [7, s. 40]. According to the memoirs of E. Pavlovich the doctor's family created the special atmosphere of hospitality and the presence of the Homeland for all the exiles, that opened a "new period" in their lives [7, s. 40]. Probably such an impression was created by the fact that the doctor came with all his numerous family members, and this family managed to create the sense of home for other lonesome exiles.

Not only the governor took an active interest in exiles. Thus, many wealthy residents of Olonets opened their doors for the exiles, as they missed the smart and intelligent society.

Especially valuable for the town residents was the Polish choral singing. A lot of citizens came to the improvised concerts to listen to the national, religious songs and even the National Polish Anthem. Extremely popular among the Olonets residents was "Boże, coś Polskę» [7, s. 41] that originally was written as the variation of "God, save the King". But after it sounded as the anthem of many rebellions, for what it was even called the Polish Marseillaise, it was forbidden in Russia after 1863 [9].

The most important factor of the preservation of the national identity among the Polish in the Olonets province was the religious one. The official representatives of the roman catholic clergy attended Olonets very rarely $-1-2$ times a year. In such conditions for the maintenance of the religious life of the Polish the important part played the exiled priests, whom was strictly forbidden to carry out the pastoral ministry. They held church services [7, s. 38] and private occasional offices [5] secretly.

The exiled priests had a difficult financial situation and one of the main sources of income was holding church services for a fee [5]. The priests lived by the remittances from the Homeland and also borrowed money from more wealthy exiles.

Meanwhile, the priests received a special attention from the officials: they searched the priests' flats and monitored the implementation of the ban on the church services. That made them hide the religious objects in the flats or even hold the services secretly in the woods [5].

In spite of the bans, searches and monitoring of private correspondence they didn't give up the ideas of national struggle $[10$, s. 5-6], and due to that they became a reliance for the exiles, supporting in them their national spirit. For example, the III Department characterized the exiled priest Ignatii Zhaba as "angry and fanatical adherent of Catholicism always ready to stigmatize in all sins the Russian Government" [10, s. 6]. The example of the priests' activity aimed at national cohesion of the exiles were the sermons of the priest Victor Mostsitskiy from the town of Plotzk, who managed to insert the seditions into his speech during the church services $[10$, s. 6].

The exiled priests keeping their faith, performing the religious ceremonies even under threat of punishment were the moral support for all the exiled Polish people both newly arrived and those ones living a long time in Olonets.

\section{Conclusion}

The social-cultural aspect of life of the Polish population in the North-West of Russia was a strengthening foundation creating the unified Polish community. This was in the Olonets province: the activity of the exiled priests, school, concerts, conversations, common reading didn't allow the Polish to vanish in the hostile environment and lose the national identity. The active cultural activity of the Polish exiles in the Olonets province in the mid-to-late 19th century contributed to the consolidation of allthe Polish population in the province and stack the community of the Russified Polish together, and also contributed to the revival of their national identity. Despite the fact that the number of colonies was small they influenced significantly on the social-cultural life of the region, as well as the demographical and ethnical balance.

\section{Agreement}

This research was supported by grant No 19-18-00073 "National Identity in the Imperial Politics of Memory: History of the Grand Duchy of Lithuania and the PolishLithuanian State in Historiography and Social Thought of the 19th - 20th Centuries" of the Russian Science Foundation.

\section{References}

1. A. Yu. Dvornichenko, R.-E. A. Kudrayvtseva, The Phenomenon of Great Duchy of Lithuania in a Scholar Discourse on the Boundary of Millenniums, Bylye Gody. Russian historical magazine 3(53), 935-955 (2019)

2. M. S. Belousov, A. S. Belousov, Russian intellectuals and the Polish issue in the late 18th early 19th century, Voprosy Istorii, 1, 107-12 (2020)

3. A. E. Kotov, Polish Problem in "Bulletin of SouthWestern and Western Russia" journal (1862-1864), Nauchnyj dialog 8, 258-27 (2019)

4. The Karelian National-cultural Autonomy of the poles. Available online: https://avt-polakov.3dn.ru (2020)

5. R. O. Aleksandrov, Living Conditions of Polish exiled priests in Olonets province in the second half of the XIX century. Available online: https://kizhi.karelia.ru/library/ryabininskie-chteniya2015/1472.html (2020) 
6. A. M. Pashkov, Political exile to Olonets province during the reign of Alexander II (1855-1881), Proceedings of the Historical faculty of Saint Petersburg University, 233-249 (2014)

7. A. B. Opracowała, Na Nieznane Losy Między Otoncem a Jadryniem. Dwa pamiętniki z zesłania po powstaniu styczniowym (Warszawa, 1999)

8. E. Samylovskaya and R-E. A. Kudryavtseva, Preservation of historical and cultural traditions of the Polish population in the Arctic of the second half of the XIX century: illustrated with the example of Arkhangelsk province, IOP Conf. Ser.: Earth Environ. Sci. 554, 012001 (2020)

9. A. G. Piotrowska, Polskie pieśni o funkcji hymnu narodowego, Nationalities Affairs 24-25, 155-161 (2004)

10. D. V. Makarov, Priests of the Kingdom of Poland in Olonets political exile in the 60-90s of the XIX century, Bulletin Of the Museum of history of the Ministry of internal Affairs of Karelia 3, 3-15 (2004) 